\title{
Retention of Listeria and Salmonella cells contaminating skim milk by tangential membrane microfiltration ("Bactocatch" process)
}

\author{
MN Madec, S Mejean, JL Maubois * \\ INRA, Laboratoire de Recherches de Technologie Laitière, \\ 65, rue de St-Brieuc, 35042 Rennes Cedex, France
}

(Received 20 February 1992; accepted 24 March 1992)

\begin{abstract}
Summary - Retention by tangential membrane ultrafiltration of non-virulent Listeria and Salmonella cells whose morphological and physiological characteristics were close to pathogenic strains was studied. The bacteria were added to raw milk, pasteurized milk or previously microfiltered milk. Decimal reductions observed at $35^{\circ} \mathrm{C}$ were close to 1.9 units for Listeria and 2.5 units for Salmonella. The reduction was not influenced by contamination level (between $10^{2}$ and $10^{6}$ $\mathrm{CFU} / \mathrm{ml})$. An increase of microfiltration temperature resulted in a significant increase of Salmonella retention (only $0.05 \%$ of the bacteria added was found in the micro-filtered milk) but had no effect on Listeria retention. The possible obtention of cheeses made from raw milk with a satisfactory level of hygiene is discussed.
\end{abstract}

milk / microfiltration / Salmonella / Listeria

Résumé - Rétention de Listeria et Salmonella par le procédé de microfiltration tangentielle "Bactocatch". La rétention de souches avirulentes, mais de caractéristiques morphologiques identiques à celles des souches pathogènes de Listeria monocytogenes et de Salmonella typhimurium par la membrane de microfiltration mise en œuvre dans le procédé "Bactocatch" a été étudiée. Ces bactéries étaient ajoutée à du lait cru, à du lait pasteurisé et à du lait préalablement microfiltré. Les réductions décimales observées étaient voisines de 1,9 unités pour Listeria et de 2,5 pour Salmonella à $35^{\circ} \mathrm{C}$. Elles n'étaient pas influencées par le niveau d'ensemencement, étudié entre $10^{2}$ et $10^{6}$ $U F C / m I$. L'élévation de la température de microfiltration à $50^{\circ} \mathrm{C}$ n'avait pas d'influence significative sur la rétention des Listeria mais accroissait significativement la rétention des salmonelles (seulement $0,05 \%$ des populations ajoutées était alors dénombré dans le lait microfiltré). La possibilité de garantir des fromages de lait cru de qualité hygiénique satisfaisante grâce à l'emploi du procédé Bactocatch est discutée.

lait / microfiltration / Salmonella / Listeria

* Correspondence and reprints 


\section{INTRODUCTION}

Despite an extended variation reported according to country, Griffiths (1989) estimated that Listeria monocytogenes occurs in less than $5 \%$ of collected milks. The level of Listeria in raw milk is estimated to be 10 $\mathrm{CFU} / \mathrm{ml}$ (Beckers et al, 1987). Thus, bulked silo milk probably contains 0.5 $\mathrm{CFU} / \mathrm{ml}$ of Listeria. But Listeria monocytogenes is able to grow at low temperatures (Donnelly and Briggs, 1986) and taking into account a lag phase of $24-48 \mathrm{~h}$ and a generation time of $20 \mathrm{~h}$, it can be assumed that even after $96 \mathrm{~h}$ of low temperature storage, untreated milk would approach levels of 5 to $10 \mathrm{CFU} / \mathrm{ml}$ (Griffiths, 1989). Information on the concentration of Salmonella cells in raw milk supplies seems to be lacking in the literature (Marth, 1969) but it is likely that contamination of raw milk by Salmonella is similar to that of Listeria (Johnson et al, 1990).

HTST pasteurization has been shown to reduce $L$ monocytogenes populations by $3.7 \log$ units (Bunning et al, 1988) and Salmonella counts by more than $5 \mathrm{log}$ units (d'Aoust, 1989). Consequently, dairy products made from pasteurized milk, if not recontaminated post-process, are hygienically safe. Cheesemaking characteristics of raw milk and organoleptic qualities of ripened cheeses are altered by heat treatment. Consequently, most French and European cheeses defined by law as "Fromages d'appellation d'origine contrôlée" are made from raw milk which with its natural flora gives a unique flavour to the resulting products. Such cheeses must evidently be totally safe for consumption.

From the results recently generated by our laboratory (Trouvé et al, 1991) on the bacterial epuration of raw skim milk through the use of membrane microfiltra- tion (MF) technology ("Bactocatch" process), we have examined specific retention by the $1.4-\mu \mathrm{m}$ pore diameter MF membrane of Listeria and Salmonella cells added to various skim milks. Our purpose was to quantify this specific retention as a function of MF temperature and levels of added cells.

\section{MATERIAL AND METHODS}

\section{Bacterial strains}

Listeria innocua No 80.11 was a gift of Institut Pasteur (Paris). This strain was chosen because it is of the same size and has the same optimal growth temperature $\left(37^{\circ} \mathrm{C}\right)$ as Listeria monocytogenes without pathogenicity, and is consequently easy to handle. Growth was conducted at $30^{\circ} \mathrm{C}$ for $48 \mathrm{~h}$ in tryptic soy broth (TSB) (Biokar OBK 028). Enumeration $\left(24 \mathrm{~h}\right.$ at $37^{\circ} \mathrm{C}$ ) in TSB and in artificially contaminated milks samples was carried out on modified Oxford medium (AES 151 992) supplemented with selective components mixture (cefotetan, cycloheximide, colistine and fosfomycine) (AES 184 122) when the natural milk flora was high compared to the level of Listeria.

Salmonella abortus ovis used in this study was a gift from Dr Pardon (INRA, Tours). It was a non-virulent strain of similar size $(3-4 \mu \mathrm{m} ; 0.6$ $\mu \mathrm{m})$ to the pathogenic counterpart. Growth was also conducted on TSB (Biokar No OBK 028) at $30{ }^{\circ} \mathrm{C}$ for $48 \mathrm{~h}$. Enumeration was performed on tryptic soy agar (TSA) (Difco 0369-01) supplemented with an antibiotics mixture (Pardon, personal communication) after $48 \mathrm{~h}$ at $37^{\circ} \mathrm{C}$.

\section{Milks utilized and levels of artificial contamination}

Three types of milk were inoculated with 3 levels $\left(10^{6} \mathrm{CFU} / \mathrm{ml} ; 10^{4} \mathrm{CFU} / \mathrm{ml} ; 10^{2} \mathrm{CFU} / \mathrm{ml}\right.$ of both Listeria and Salmonella cultures in the feed vat of the microfiltration equipment. The milk examined in this study consisted of: raw bulk skim 
milk with less than $0.05 \%$ fat and a total mesophilic flora of around $10^{5} \mathrm{CFU} / \mathrm{ml}$; HTST pasteurized $\left(72{ }^{\circ} \mathrm{C} ; 15 \mathrm{~s}\right)$ bulk skim milk with less than $0.05 \%$ fat and a total mesophilic flora of around $10^{4} \mathrm{CFU} / \mathrm{ml}$ and HTST pasteurized $\left(72{ }^{\circ} \mathrm{C} ; 15 \mathrm{~s}\right.$ ) bulk skim milk, "Bactocatch" treated as described by Maubois (1991) with a total mesophilic flora of around $10^{2} \mathrm{CFU} / \mathrm{ml}$.

\section{Microfiltration experiments}

Bacterial retentions were studied with MFS-1 Alfa-Laval equipment, containing a 1 P 19 Membralox (SCT Tarbes, France) 1.4- $\mu \mathrm{m}$ pore size cartridge $(0.85 \mathrm{~m}$ length; internal diameter of the channels: $4 \mathrm{~mm}$; area $0.2 \mathrm{~m}^{2}$ ). Hydraulic system was obtained with 3 centrifugal pumps: a feeding pump giving an inlet flow of $147 \mathrm{I} . \mathrm{h}^{-1}$ and maintaining inlet MF pressure at $3.2-3.5$ bars; a retentate recirculation pump allowing a MF membrane recirculation speed of $5.8 \mathrm{~m} . \mathrm{s}^{-1}$; a microfiltrate recirculation pump giving a uniform transmembrane pressure of 0.55 bar and a recirculating flow of $500 \mathrm{I} \cdot \mathrm{h}^{-1}$.

Extraction fluxes were maintained at $700 \mathrm{l}$. $\mathrm{h}^{-1} \cdot \mathrm{m}^{-2}$ for the microfiltrate and $35 \mathrm{I} \cdot \mathrm{h}^{-1} \cdot \mathrm{m}^{-2}$ for the retentate, ie a volumic concentration of 20 . Microfiltrate and retentate were continuously recycled; 30 I of milk were used for each experiment.

Two temperatures $\left(35^{\circ}\right.$ and $\left.50^{\circ} \mathrm{C}\right)$ were investigated. Samples were aseptically taken out through septums inserted in feed and recirculation loops pipes, every $3 \mathrm{~min}$ after a period of 10 min following addition of the bacterial cultures to the feed vat.

\section{RESULTS AND DISCUSSION}

\section{Effects of milk pretreatments on Listeria cells retention by $M F$}

Table I shows decimal reduction observed at $30{ }^{\circ} \mathrm{C}$ on raw skim milk, "premicrofiltrated" pasteurized skim milk and pasteurized skim milk artificially contaminated with $10^{6} \mathrm{CFU} / \mathrm{ml}$ Listeria cells. Each result is the average of 16 enumerations (4 successive enumerations and 4 experiments).

The MF membrane used in "Bactocatch" equipment retained $99.5 \%$ of Listeria innocua cells added in raw skim milk achieving a decimal reduction of $2.28 \pm$ $0.17 \log$ units. No significant difference was observed with pasteurized skim milk: the decimal reduction was $2.14 \pm 0.16 \mathrm{log}$ units. Such results agree well with the previous observations of Trouvé et al (1991). Listeria innocua has a cellular volume similar to that of Pseudomonas fluorescens for which Trouvé et al (1991) found a decimal reduction of 2.12 log units.

Retention of Listeria cells was much lower when "premicrofiltrated" milk was investigated. Only $95 \%$ of added cells were retained by the $1.4-\mu \mathrm{m}$ pore size membrane. No evident reason appears to explain this result. Milk from "Bactocatch" equipment does not contain any somatic cells (Maubois, 1991), and there might be some interaction between leucocytes and Listeria as shown by Doyle et al (1987) favouring MF Listeria retention in raw and

Table I. Decimal reductions (DR) observed with the different milks inoculated with $10^{6}$ Listeria cells $/ \mathrm{ml}$.

Réductions décimales observées sur les différents laits inoculés avec $10^{6}$ cellules/ml de Listeria.

Types of milk $\quad D R^{*}$

Raw skim milk

HTST pasteurized skim milk

Premicrofiltrated HTST

pasteurized skim milk

$2.28 \pm 0.17$

$2.14 \pm 0.16$

$1.30 \pm 0.16$

- Average of 16 trials (log inlet milk-log outlet microfiltrate). 
pasteurized skim milk. Another hypothesis is that premicrofiltration of milk leads to a general reduction of milk components involved in the fouling of the $1.4-\mu \mathrm{m}$ membrane and consequently, membrane transfer of Listeria cells during the subsequent MF would be easier because of reduced fouling. More work is required to understand this phenomenon.

\section{Effect of contamination level and temperature on Listeria and Salmonella cells retention by MF}

Table II summarizes the different results obtained with 3 levels of contamination and 2 temperatures with HTST pasteurized skim milk. This type of milk was chosen because enumeration of Listeria cells added at the lowest level ( $\left.10^{2} \mathrm{CFU} / \mathrm{ml}\right)$ was easier than in raw skim milk.

Decimal reduction of both Listeria and Salmonella cells is similar, regardless of the level of artificial contamination. Such results agree with those of Trouvé et al
(1991) and Jaubert et al (1991) who also found that MF membrane acts as a depth filter and not as a screen filter.

MF membrane with 1.4- $\mu \mathrm{m}$ pore size showed a better retention of Salmonella cells than Listeria cells. This may be related to the larger cellular volume of Salmonella. At $35^{\circ} \mathrm{C}, 99.7 \%$ of Salmonella cells are retained in the MF retentate compared with $98.6 \%$ for Listeria cells. Heating milk to $50{ }^{\circ} \mathrm{C}$ increases decimal reduction of Salmonella by MF treatment because of heat sensitivity of this bacterial genus (D value at $51.8^{\circ} \mathrm{C}$ is $1.267 \mathrm{~s}$ for $S$ typhimurium according to Bradshaw et al, 1987). Consequently, holding contaminated milk at $50{ }^{\circ} \mathrm{C}$ for $20 \mathrm{~min}$ in association with a MF treatment removes $99.95 \%$ of Salmonella flora initially present in milk. Temperature has a much less significant effect on Listeria, which is known to be more heatresistant than Salmonella. Listeria D value at $63.3^{\circ} \mathrm{C}$ is $33.3 \mathrm{~s}$ (Bunning et al, 1986) compared with $6.7 \mathrm{~s}$ for Salmonella (Bradshaw et al, 1987). On the other hand, heat treatment applied to Listeria contaminated

Table II. Decimal reductions (DR) observed at different levels of contamination with Listeria and Salmonella at $35^{\circ} \mathrm{C}$ and $50^{\circ} \mathrm{C}$.

Réductions décimales observées à différents niveaux de contamination en Listeria et Salmonella à 35 et $50^{\circ} \mathrm{C}$.

$D R$

Listeria innocua Salmonella abortus ovis

Level of contamination $35^{\circ} \mathrm{C}$

MF temperature
$10^{2} \mathrm{CFU} / \mathrm{ml}$

$10^{4} \mathrm{CFU} / \mathrm{ml}$

$10^{6} \mathrm{CFU} / \mathrm{ml}$
$1.81 \pm 0.18$

$1.83 \pm 0.39$

$1.87 \pm 0.31$

$1.85 \pm 0.38$

$1.99 \pm 0.21$
$2.46 \pm 0.10$

$2.37 \pm 0.13$

$2.46 \pm 0.16$ $35^{\circ} \mathrm{C}$

$50^{\circ} \mathrm{C}$

$2.52 \pm 0.22$

$3.30 \pm 0.19$

$10^{6} \mathrm{CFU} / \mathrm{ml}$ added 
milk in the MF equipment $\left(50^{\circ} \mathrm{C} ; 20 \mathrm{~min}\right)$ is in the neighborhood of the conditions $\left(56{ }^{\circ} \mathrm{C}\right.$; $50 \mathrm{~min}$ ) recently described by Busch and Donnelly (1992) as injuring Listeria cells and minimizing enumeration on TSB medium. Nevertheless, if such an injury did occur with the Listeria strain used it was the same for retentate and microfiltrate populations, both liquids being recycled in our trials, and consequently could not affect the determined decimal reduction.

\section{CONCLUSION}

Use of the "Bactocatch" process for treating skim milk at $50{ }^{\circ} \mathrm{C}$ reduces 99.0 and $99.95 \%$ Listeria and Salmonella populations respectively. Such a bacterial reduction is not as effective as pasteurization, but it could be relatively satisfactory when cheesemaking with raw milk is envisaged. "Bactocatch" treatment of raw milk containing $0.5-10 \mathrm{CFU} / \mathrm{ml}$ of potentially pathogenic Listeria and Salmonella species (Griffiths, 1989), according to the process described by Maubois (1991) with an UHT sterilization of cream to be added for fat standardization and a MF treatment of skim milk will allow a count between 2-40 CFU $/ 1000 \mathrm{ml}$ in cheese milk. Envisaging that $90 \%$ of these contaminating bacteria will be kept in the $100 \mathrm{~g}$ of cheese resulting from the original $1000 \mathrm{ml}$ of cheesemilk leads to $0.2-4$ Listeria or Salmonella cells per $10 \mathrm{~g}$ of cheese. Such a hypothetical calculation gives a result which could be in the upper part of the range slightly higher than the French regulation (no Listeria in $25 \mathrm{~g}$ of cheese (Dehove, 1991) but taking into consideration a likely constant increase in hygiene at milk production and processing, it can be claimed that use of microfiltration will considerably increase the safety of raw milk cheeses.

\section{ACKNOWLEDGMENT}

This study was financially supported by Bretagne Biotechnologies Alimentaires Association, Rennes and INRA.

\section{REFERENCES}

Beckers HJ, Soentoro PSS, Delfgou van Asch EHM (1987) The occurrence of Listeria monocytogenes in soft cheeses and raw milk and its resistance to heat. Int J Food Microbiol 4, 249-256

Bradshaw JG, Peller JT, Corwin JJ, Barnett JE, Twedt RM (1987) Thermal resistance of disease-associated Salmonella typhymurium in milk. J Food Prot 50, 95-96

Bunning VK, Crawford RG, Bradshaw JG, Peeler JT, Tierney JT, Twedt RM (1986) Thermal resistance of intracellular Listeria monocytogenes cells suspended in raw bovine milk. Appl Environ Microbiol 52, 1398-1402

Bunning VK, Donnelly CW, Peeler JT, Briggs EH, Bradshaw JG, Crawford RG, Beliveau CM, Tierney JT (1988) Thermal inactivation of Listeria monocytogenes within bovine milk phagocytes. Appl Environ Microbiol 54, 364370

Busch SV, Donnelly CV (1992) Development of a repair-enrichment broth for resuscitation of heat-injured Listeria monocytogenes and Listeria innocua. Appl Environ Microbiol 58, 1420

D'Aoust JY (1989) Contemporary concerns on the microbiological safety of milk and dairy products. Proc Int Sem Santander (Spain) 15-37

Dehove RA (1991) Réglementation des produits. In: Qualité et Répression des Fraudes (Lamy SA, ed) Vol II, 14-85

Donnelly CW, Briggs EH (1986) Psychotrophic growth and thermal inactivation of Listeria monocytogenes as a function of milk composition. J Food Prot 49, 994-998

Doyle MP, Glass KA, Berry JT, Garcia GA, Pollard DJ, Schultz RD (1987) Survival of Listeria monocytogenes in milk during high temperature, short time pasteurization. Appl Environ Microbiol 53, 1433-1438 
Griffiths MW (1989) Listeria monocytogenes: its importance in the dairy industry. J Sci Food Agric 47, 133-158

Jaubert G, Costes P, Guyonnet P, Gay MF, Pierre A, Maubois JL (1991) Traitement du lait de chèvre par microfiltration en flux tangentiel. Process 1006, 62-67

Johnson EA, Melson JH, Johnson M (1990) Microbial safety of cheese made from heat treated milk. Part II. Microbiology. J Food Prot 53, 519-540
Marth EH (1969) Salmonellae and salmonellosis associated with milk and milk products. A review. J Dairy Sci 52, 283-315

Maubois JL (1991) New applications of membrane technology in the dairy industry. Aust $J$ Dairy Technol 46, 91-95

Trouvé E, Maubois JL, Piot M, Madec MN, Fauquant J, Rouault A, Tabard J, Brinkman G (1991) Rétention de différentes espèces microbiennes lors de l'épuration du lait par microfiltration en flux tangentiel. Lait 71, 1-13 